Palestine Exploration Quarterly

\title{
Notes
}

\section{Conrad Schick}

To cite this article: Conrad Schick (1887) Notes, Palestine Exploration Quarterly, 19:1, 50-55, DOI: $10.1179 /$ peq.1887.19.1.50

To link to this article: http://dx.doi.org/10.1179/peq.1887.19.1.50

曲 Published online: 20 Nov 2013.

Submit your article to this journal

LII Article views: 6

Q View related articles $\longleftarrow$ 


\section{NOTES.}

\section{The Stones of Jerusalem.}

TIr reddish rock "misseh" is to be found in the valley in which the Convent of the Cross is situated, even northwards to the watershed, but it is also found on other places west (not east) of Jerusalem. But I have to mention that the word "misseh" does not only mean this reddish stone, but also others which are white or green: it is the classification of hardness, not of colour.

At Jerusalem there are the following classes of stones :-

1. Hower, very soft chalk, hardly to be called rock, as it is so soft and brittle. Pounded and mixed with lime it makes the mortar for fireplaces and bake-ovens.

2. Soft Kakooli, a kind of chalk, and white, soft.

3. The common Kakooli, a soft limestone, easy to be dressed; many houses ar huilt from it, the best is brought from the east side of Mount Olivet and anathoth, but it is found also in other places.

4. Nahreh, a kind of conglomerate, in various degree of hardness, some so brittle that it falls by-and-by to sand; others bordering on flint ; between them a great variety. Nahreh means the firestone-i.e., the stone which stands against fire. All others crack when heated or become lime; not so this one, so all fireplaces and ovens are made with it when bricks cannot be had. As they are also especially light (not heavy), so they are used for the arching of the vaults, in new (and found in old) houses.

5. Then comes a stone between Kakooli and Meleki, very often used at building, as the dressing is easy ; then comes-

6. Meleki, or the royal rock, the best stone for dressing and building ; as it is not so hard as Misseh it cannot easily be dressed, and thus it stands against the atmosphere, as the Kakooli is affected more or less by the latter, and by wet and frost, not so the Meleki.

Of this there are of various degrees: some era intermixed with other stuff and so exposed to breachings, \&c. ; then comes-

7. Misseh, of which there are several kinds :-

(a) Soft Misseh, white.

(b) Soft Misseh, reddish.

(c) Hard Misseh, reddish or white.

(d) Hard Misseh, white or green, or some yellowish.

(e) The hardest Misseh, or Jehudeh, as the workmen call them, as it is - most difficult to deal with them.

( $f$ ) Flint, generally brown, interwoven with white stripes.

Then there are also some more in regard of the size and form of the stones :-

Gardad-Flat, hard, about 8 inches to 1 foot thick, and 3 or more feet long, broken out from layers. 
Makatim-Of the same form but nuch smaller, only 3 to 4 inches thick, generally used for arches, as they are very hard and durable, and easily worked to arches.

Akkat-The general arch-stones, rough, flat pieces, not hewn, mostly made of the Nahreh, for cisterns and arches which must be strong, also from Kakooli or Misseh.

Shakat means, generally, simply stones for a wall of the size that a camel may bear two of them.

Akkabe-Long and narrow stones for thresholds or lintels for door and windows.

\section{Newly discovered Rock-hewn Tomb at Kolonieh.}

IN winter 1877-8 became by the nuch rain the brook at Kolonieh to a grand strean, which carried off one of the arches of the stone bridge there. As the pier had also gone, so in winter it could not be repaired; but in order not to stop communication a wooden bridge was quickly made, which lasted for seven years, but had to be replaced by a stone one, which was done in 1885 , and stones for it squared in the neighbourhood ; by doing so a rock-hewn tomb was discovered. The proprietor of the ground came to me saying that he had found a cave, and in it tombs, paintings, and other things, and that I should go and see it. In general, reports of this kind are exaggerated, yet Kolonieh proved an exception; for I went next day, 31st August, there, and found more than I had expected. About $5(00$ to 600 feet south-east of the bridge in a vineyard the opening was shown to me. The arrangement was of a kind which I had not seen before anywhere. It will be understood from figs. 1 and 2 of the adjoining plans and sketches.

When the earth of a few feet thick had been removed there were four long and narrow stone slabs horizontally laid (see figs. 2 and 4), and when these were taken off there was a hollow or small artificially made cave, the slabs resting on one side in a groove in the rock scarp, on the other of some masonry, as the rock there was not high enough. Across this little cave was, along the scarp wall, a vertical hole, and in it an upright stone flat, of equal thickness, $(a)$ of a square form, a rock ledge $(b)$ keeping it in this situation. Towards the upper end the stone has a hole through which a rope might be slung, and so by pulling it might be lifted upwards and out of its position, and by this means the tomb opened.

The opening (only about 1 foot thick) in the rock scarp wall is square, about 1 foot 6 inches wide, and 1 foot 10 inches high. Inside there is, 1 foot 5 inches lower, a 1 foot 1 inch broad stone bench, and from it three steps led down to the bottom of the rock-hewn chamber, 4 feet deeper (or lower) than the lower part of the entrance. The cave or chamber has a square form, but as the plan (fig. 1) shows on the side of the

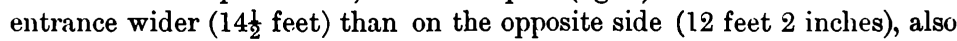
the other two sides are differing, the northern 10 feet, the southern 11 feet. 
52 NEWLY DISCOVERED ROCK-HEWN TOMB AT KOLONIEH.

Fig. 1.

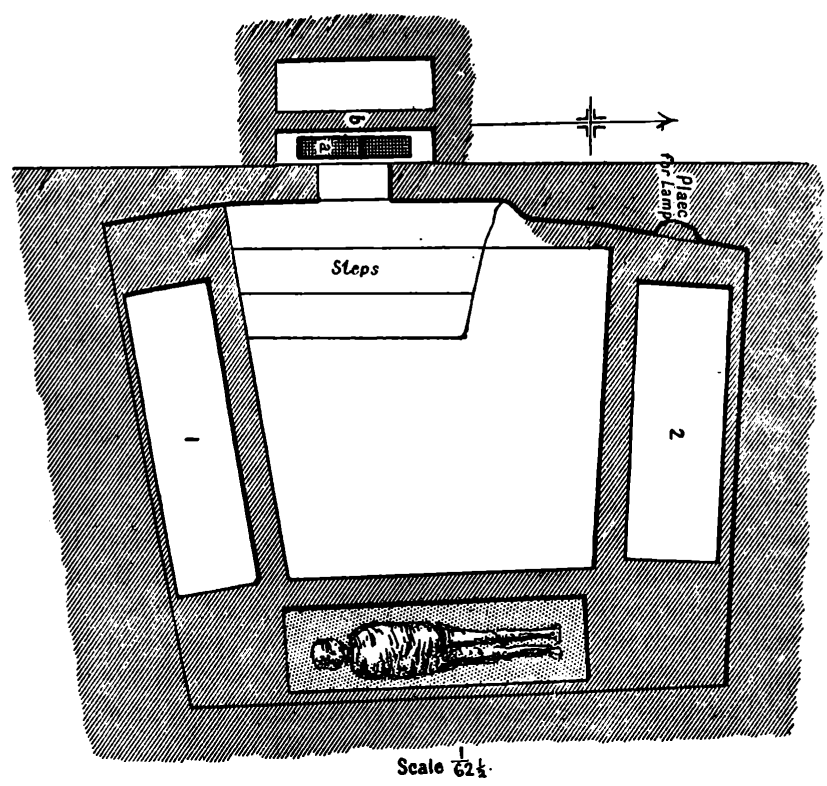

F19. 2.

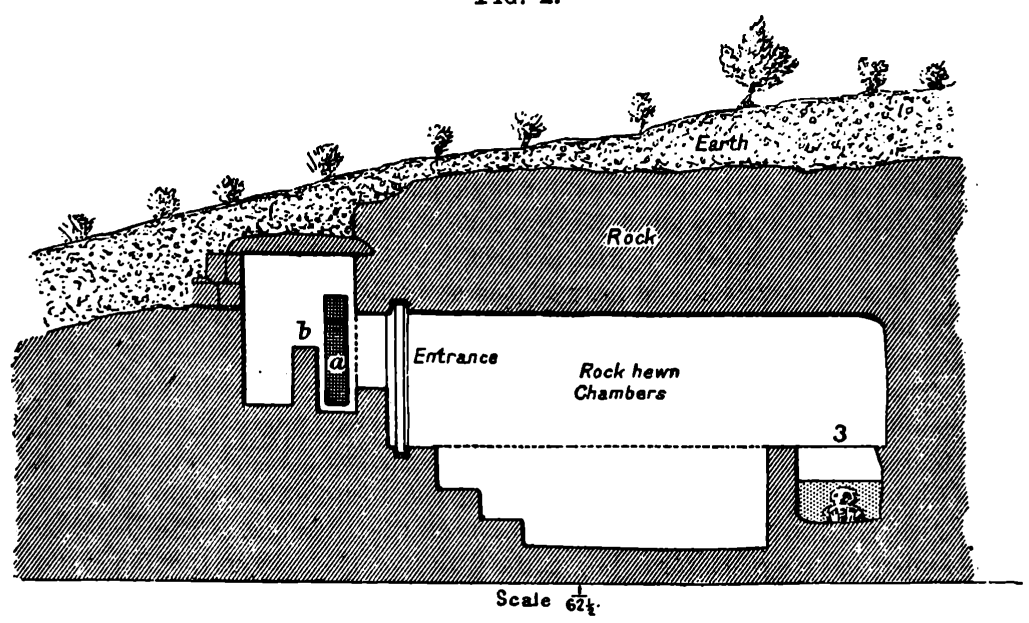


The height is on an average 5 feet $6 \frac{1}{2}$ inches, the botton even, but the ceiling a little shelving or inclined. On three sides there are rock-hewn troughs or tombs, each very nearly 2 feet wide, 1 foot 9 inches deep (cut perpendicular), and on an average 6 feet 6 inches long. The shortest width, 6 feet 2 inches, is the northern, and the longest width, 7 feet 3 inches, the southern. In these two latter, Nos. 1 and 2, there was human dust intermixed with a few very decayed bones, but in the eastern width, No. 3, which is toward the hill (as fig. 2 shows), I found nearly full of water, and in it a preserved skeleton, and, as I afterwards learned, of a

FIG. 3.

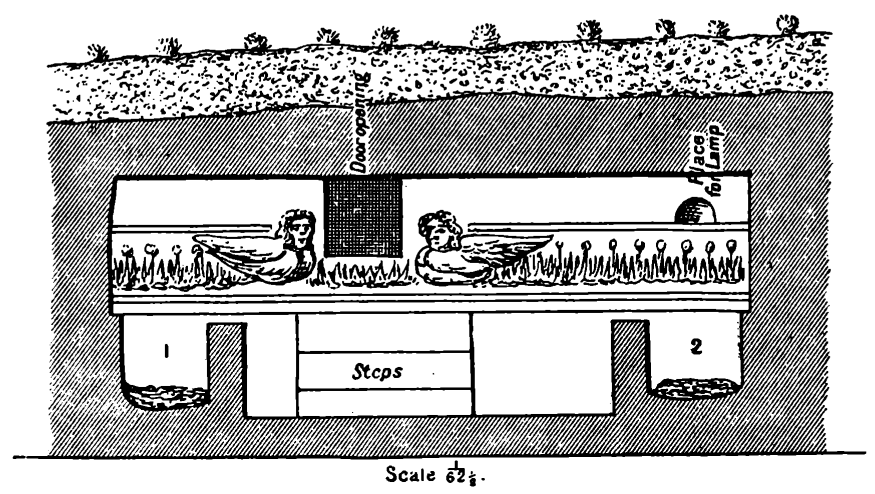

woman. It seems the water coming out from the higher layer of the rock learing with it some lime stuff, covered the bones with stalactite and preserved them, as in the other two there is only moisture, but no water, and so the decaying took place.

But the most remarkable thing I found was fresoo painting on the walls, being first plastered, and the painting (still in very good preserved colours) afterwards put on. On the ceiling there is no plaster, but the painting put on the rock surface and afterwards burnished, as it looks still so. On the north and west sides the paintings are still visible, but by moisture decayed so much that nothing can be comprehended or made out; the western and southern sides were preserved when the cave was opened, but a few days after the plaster fell off. As I came soon enough I could copy them, which I give in the drawings. There are red stripes or lines, and between green leaves with red flowers, and in the middle a pair of winged figures with heads of a child, i.e., cherubim; they look very friendly, and have black hair; the body like a dove.

On the west side there is between them the entrance hole, but between the pair on the south side is a green wreath (of green leaves) bound at the bottom with a brown riband, its ends hanging down ending in heartshaped forms. 
Frg. 5.

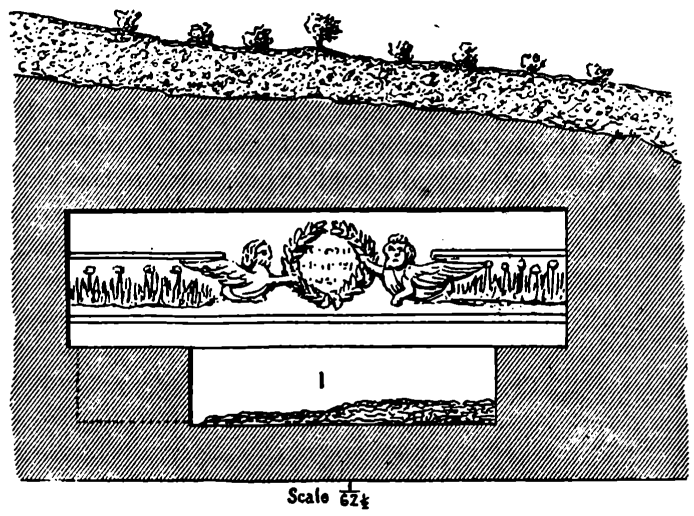

And in the field, inside the garland is a Greek inscription, the cherubin having each only one are holding the wreath. Similar drawings are on the ceiling (see drawing No. 6); there are also two branches of brown colour. These figures on the ceiling are much larger and of full human

Fir. 6.

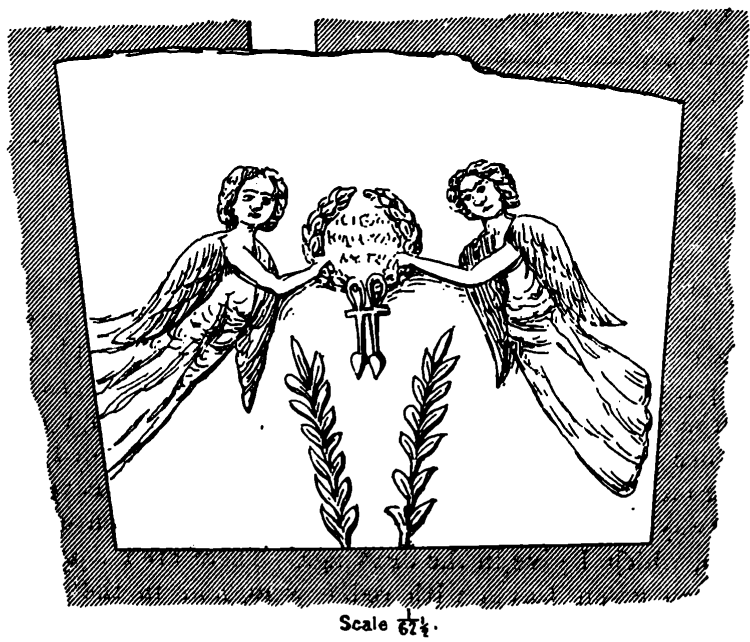

size, or rather even larger, and have long garments, but also only one arm. No cross could be found anywhere, nor on the heads of the figurcs any rings as of saints; still the inscriptions declare the tombs to be Christian. On the western wall inside there is a niche for a lamp, and the upper part is blacked, so that it must have been used in such a way. 
On the rock bench inside the entrance there were lying a quantity of

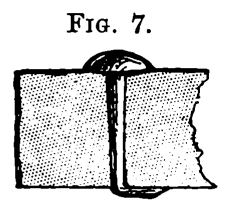
large iron nails, with remarkably large round heaclu, and the points bent or rivetted; also an iron ring (see No. 7, where it is given on a larger scale), formerly ajpparently belonging to a wooden door, which must have been (according to the nails) $3 \frac{1}{2}$ inches thick. On the rock are holes for the upper and lower hinges of the apparently wooden door, and for the bolt in

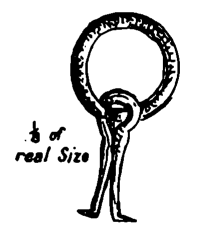
the middle on the other side. The wood was entirely rotten, and nothing left of it.

It is curious that although the tomb could be shut up with the stone slab above described, yet a wooden door was made. This gives me the idea that the tomb may have been originally Jewish, and then afterwards used by Christians, or (and this is much more likely the case) the tomb was for a certain time used as a kind of a chapel, or an anchoret lived there for a time.

Fur. 8.
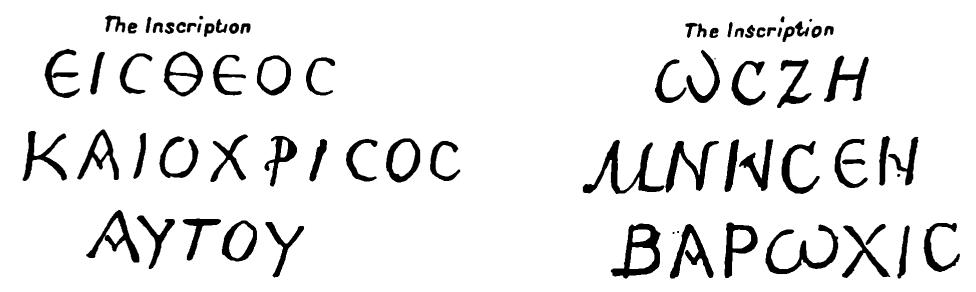

The Russian Archimandrite told me that the figures and inscriptions belong to the third century, and that the inscription on the wall is the words of the malefactor on the Cross, "Lord, remember me." The one on the ceiling to be read: "God and His anointed" (Christos).

Jerusalem, November, $10 t h, 1886$.

Conrad Schick.

\section{THE SIZE OF THE "CITY OF DAVID."}

This topic is touched upon by C. R. C. in a short paragraph in page 82 of the Quarterly Statement for April, 1886, and one is surprised to find that, after passing by, without reply, the chain of evidence brought forward by the Rev. W. F. Birch in the Quarterly Statement for 1885, and in the January number of the current year $;$ he should have seized upon the mere indicittion (in a plan) of the area within which it is suggested by Mr. Birch that excavations should be made, in order to search for the sepulchres of the Kings.

I can scarcely understand how it is that all the indications which point 